DOI https://doi.org/10.30525/978-9934-26-180-0-25

\title{
МУЛЬТИМОДАЛЬНІ ХАРАКТЕРИСТИКИ КОНФЛІКТИВУ У СУЧАСНОМУ АНГЛІЙСЬКОМОВНОМУ ХУДОЖньОМУ ДИСКУРСІ
}

\author{
Черненко О. В. \\ кандидат філологічних наук, \\ доцент кафедри германської і фіно-угорської філології \\ імені професора Г. Г. Почепцова \\ Київський національний лінгвістичний університет \\ м. Київ, Украӥна
}

Лінгвосеміотичний простір сучасного англомовного художнього дискурсу охоплює площини гармонізації та дисгармонізації міжособистісних стосунків художніх персонажів. Дисгармонізаційна площина формується у межах дискурсивного конструкту конфлікт, семіозис якого вибудовується когнітивно-семіотичними та комунікативно-прагматичними особливостями конфліктивів як оперативних одиниць конфлікту $[1 ; 2 ; 4]$.

Відповідно до класифікації конфліктів за різними критеріями як внутрішньо особистісні, так і міжособистісні/міжгрупові конфлікти у художньому дискурсі реалізовуються за допомогою конфліктивів, у трактуванні яких виявляється можливим виокремлення декількох векторів інтерпретації вищезазначеної одиниці: 1) лінгвопрагматичний nidxid, згідно 3 яким конфліктив трактується як мовленнєвий акт, класифікований за Дж.Лічем відповідно до ролі, яку певний мовленнєвий акт відіграє у соціальній комунікативній взаємодії партнерів, ілокутивна мета якого вступає у конфлікт 3 соціальною метою підтримання партнерства і комунікативної взаємодії через погрози, звинувачення, наклепи, прокляття тощо [4, с. 140]; 2) когнітивно-дискурсивний підхід, де конфліктив розглядається як дискурсивна стратегія конфронтації, що розгортається на тлі порушення/недотримання принципу ввічливості як особливої стратегії мовної поведінки, спрямованої на запобігання конфліктних ситуацій 3 метою "зберегти обличчя" та передбачає дотримання максим такту, щирості, схвалення, скромності, згоди, симпатії як ефективного способу соціальної взаємодії [3, с. 280]; інтегративний / комплексний підхід, згідно 3 яким конфліктив як основна оперативна одиниця дослідження конфлікту трактується як полікомпонентний та поліфункціональний дискурсивний 94 
мультимодальний конструкт, мультисеміозис якого у художньому дискурсі відбувається за гомогенними та гетерогенними моделями взаємодії вербальної, невербальної та паравербальної семіотичних систем та характеризуються дисгармонізацісю інтра та інтерперсональних стосунків комунікантів. Проілюстуємо вищезазначені характеристики на прикладах, відібраних 3 фрагментів англомовного сучасного конфліктного дискурсу.

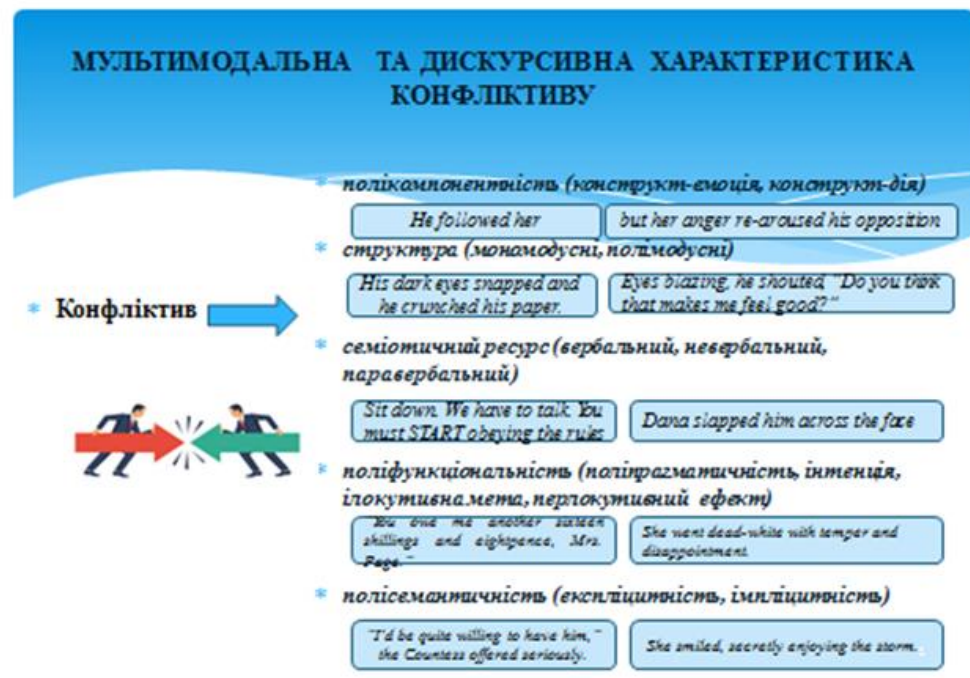

\section{Рис. 1. Мультимодальна та дискурсивна характеристика конфліктиву}

Таким чином, диференційними рисами конфліктивів визначаються полікомпонентність, конфронтаційність, мультимодальність, оцінність, комплексність, емоційність, поліфункціональність.

Проблема реалізації конфліктивів у сучасному англомовному дискурсі визначається насамперед комунікативною інтенцією, як глобальною комунікативною стратегією, що чинить вплив на адресата та задіює весь мовний та позамовних досвід людини у рамках інтерсуб'єктивності як "спільної відповідальності" за виникнення/переростання/врегулювання/ усунення конфлікту, що $є$ перспективою подальших наукових розвідок. 


\title{
Література:
}

1. Каразия Н. А. Лингвопрагматическое исследование конфликтного дискурса. Вестник КРАУНЦ. Сер.: Гуманитарные науки. 2006. № 2 (8). C. $72-88$.

2. Комалова Л. Р. Лингвистический аспект конфликтологической компетентности: автореф. дис. ... канд. филол. наук: 10.02.21. Москва, 2009. $25 \mathrm{c}$.

3. Третьякова В. С. Речевая конфликтология: проблемы, задачи, перспективы. Вестник Челябинского государственного университета. 2013. № 1 (292). C. 279-282.

4. Leech Geoffrey. Principles of Pragmatics. London, New York: Longman, 1983. $257 \mathrm{p}$.

DOI https://doi.org/10.30525/978-9934-26-180-0-26

\section{RECEPTION OF UKRAINIAN POETIC LITERARY DISCOURSE IN FRENCH-SPEAKING COUNTRIES (1961-2021)}

\author{
Chystiak D. O. \\ Doctor of Philological Sciences, Associate Professor, \\ Professor at the Department of Romanic Philology, \\ Scientific and Pedagogic Institute of Philology \\ Kyiv National Taras Shevchenko University \\ Kyiv, Ukraine
}

After the restoration of Ukraine's independence thirty years ago, literary exchanges with French-speaking countries reached a new level, although we should note some problems in the reception of works by Ukrainian authors, so the identification of achievements in this field seems relevant. The aim of this study is to characterize the current state, highlight problems and outline the perspectives for the spread of Ukrainian literary tradition in French-speaking countries._In contemporary philology, there are some valuable studies on the history of Franco-Ukrainian literary relations, which, however, relate to particular problems. The current period of the poetic literary process is either ignored or studied not as a systemic process $[2 ; 4 ; 5]$.

The $2^{\text {nd }}$ part of $\mathrm{XX}$ century is marked by the growing interest in the Ukrainian literary tradition in the French-speaking world. However, a number of publications prepared in Kyiv by the editorial board of foreign literature of 